\title{
ASSESSMENT THE KNOWLEDGE REGARDING BREAST CANCER AND BREAST SELF EXAMINATION AMONG THE STUDENTS OF V.V. VANNIAPERUMAL NURSING COLLEGE FOR WOMEN AT VIRUDHUNAGAR
}

\author{
Ms. Manimeghalai
}

\begin{abstract}
The Breast self examination is easy to learn and takes a minimum amount of time to perform each month. The basic techniques of early detection of breast cancer is BSE-Breast Self examination. Nurses have educational role concerning breast cancer. Therefore, a descriptive study was conducted among 40 BSC (N) I year students in V.V. Vanniaperumal. Nursing College at Virudhunagar. Objective of the study was to assess the level of knowledge regarding breast cancer and BSE among students. Purposive sampling technique was used. Tool consisted of self structured questionnaire to assess the knowledge of students. Results showed that 5\% (21) had good knowledge and 95\% (38) students had fair knowledge regarding breast cancer and BSE. The knowledge score had no statistical significant relationship with demographic variables.
\end{abstract}

\section{Keywords : Knowledge, Breast Cancer, Breast Self Examination}

Introduction

Breast cancer can be termed as lifestyle diseases. Breast cancer is the leading cause of cancer mortality in women worldwide. The incidence of breast cancer is rising more rapdily in population groups.

Potentially important strategy in reducing breast cancer mortality is the use of screening in achieve earlier detection of cancer. This is very important earlier detection of cancer. This is very important because of excellent prognosis is directly associated with the state at which the turn our is detected and how localized the lesion. Early diagnosis usually results in treatment before metastasis and signifies a better outcome of management.

The basic techniques of early detection of breast cancer is breast self examination as a useful care practice and the technique essentially has no adverse effect.

\section{Statement of the problem}

A study to assess the knowledge regarding breast cancer and breast self examination among the students of V.V. Vannaiperumal Nursing College for Women at Virudhunagar and to develop a need based instructional module 


\section{Objectives}

To assess the level of knowledge regarding breast cancer and BSE among Students.

To find out the association between the level of knowledge of breast cancer and BSE among students with the selected demographic variables.

\section{Methodology}

\section{Research Design}

The descriptive (Non experimental) research design was adopted for the study.

Settings

The study was conducted in V.V. Vanniaperumal Nursing College at

Virudhunagar

\section{Population}

BSC (N) I year from the V.V. Vanniaperumal Nursing College at

VirudhuNagar.

\section{Scoring}

More Relevant Answer : 2

Less Relevant Answer : 1

Wrong Answer : 0

Score Interpretaion

$\begin{array}{rcc}\text { Good } & : & 61-80 \\ \text { Fair } & : & 41-60 \\ \text { Poor } & : & 21-40 \\ \text { Very Poor } & : & 1-20\end{array}$

\section{Sample Size}

The sample consisted of 40 B.Sc., (Nursing)

Students from 1 year.

Sampling Technique

Purposive Sampling Technique was used.

\section{Criteria for Sample Collection}

The students studying B.S.c., Nursing I year in V.V. Vanniaperumal Nursing College Virudhunagar

Who are in between the age group of 17-20 years.

\section{Exclusion Criteria}

Students who are studying in the B.Sc., Nursing II, III and IV Year.

Students who are not willing to participate in the Study.

\section{Procedure for Data Collection}

After obtaining consent the subjects were made to sit comfortably in the classroom. They were explained about the method of filling the questionnaire. The data was collected for a period of 7 days (March 1 to March 7 2015). Each day 5-10 students were selected and duration of time was 3045 minutes. 
Analysis and Interpretation of Data

Table : 1

Frequency and percentage Distribution of Sample on the Basis of Level of Knowledge $(\mathrm{N}=40)$.

\begin{tabular}{|l|l|l|l|}
\hline $\begin{array}{l}\text { S. } \\
\text { No. }\end{array}$ & $\begin{array}{l}\text { Level of } \\
\text { Knowledge }\end{array}$ & Frequency & Percentage \\
\hline 1. & $\begin{array}{l}\text { a. Good } \\
\text { b. Fair }\end{array}$ & 2 & $5 \%$ \\
c. Poor & -- & $95 \%$ \\
D. Very & -- & -- \\
Poor & & -- \\
\hline
\end{tabular}

Figure 1 : Distribution of Students according to their level of knowledge

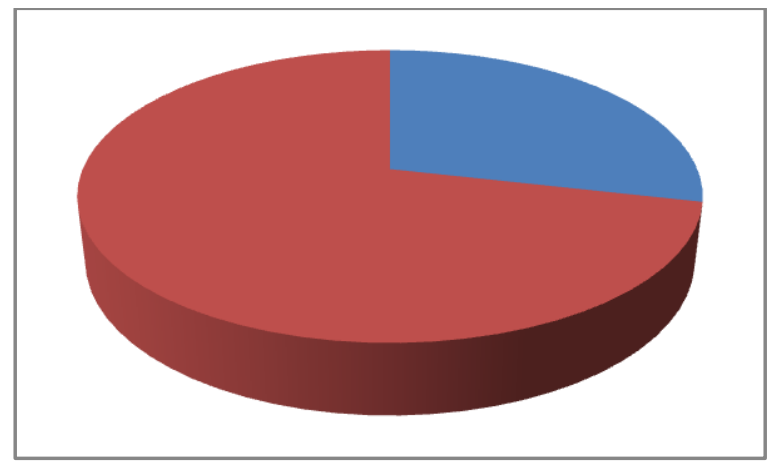

It shows that $5 \%(21)$ students were having good.

Knowledge and 95\% (38) students were having fair knowledge.

There was no significant association between the knowledge score and selected demographic variables such as age, age at puberty, parental education, occupation of parents, Menstural Cycle, Hobbies,
Domicile, Economic Status, H/o Breast

Cancer and type of family. Hence, in this study researcher rejected the research hypothesis and accepted the null hypothesis. Conclusion

The study concluded that students have some knowledge regarding breast cancer and BSE and there was no significant association between the knowledge score of breast cancer and BSE with selected demographic variables. This study also recommended for conduction of this study in non nursing students and other working women. (Regarding practice of BSE).

\section{References}

1. Polit \& Hungler (1999). Nursing research, $8^{\text {th }}$ ediion, Philadelphia, Lippincott publishers.

2. Joyce, M. Black (2009), Medical Surgical Nursing, $8^{\text {th }}$ Edition, Elsevier Publications.

3. Brunner \& Suddarth (2012), Medical Surgical Nursing, $11^{\text {th }}$ edition, Lippincott Publications.

4. Dr. T. Vasundra Tulasi (2011), Nursing Research and Statistics, First Edition, Frontline Publications.

5. Epidemiology of Breast Cancer NNT, 4 (52-54). Rehabilitating breast cancer patients, Health Action, 3(15) : 24 . 